\title{
Understanding the Quality Determinants that Influence the Intention to Use the Mobile Learning Platforms: A Practical Study
}

\author{
https://doi.org/10.3991/ijim.v13i11.10300 \\ Muhammad Alshurideh \\ University of Sharjah, UAE, UAE \\ University of Jordan, Amman, Jordan \\ Said A. Salloum ${ }^{(凶)}$ \\ University of Sharjah, UAE, UAE. \\ The British University in Dubai, UAE. \\ ssalloumesharjah.ac.ae \\ Barween Al Kurdi \\ Amman Arab University, Amman, Jordan \\ Azza Abdel Monem \\ Ain Shams University, Cairo, Egypt \\ Khaled Shaalan \\ The British University in Dubai, Dubai, UAE
}

\begin{abstract}
There is a widespread use of Internet technology in the present times, because of which universities are making investments in Mobile learning to augment their position in the face of extensive competition and also to enhance their students' learning experience and efficiency. Nonetheless, Mobile Learning Platform are only going to be successful when students show acceptance and adoption of this technology. Our literature review indicates that very few studies have been carried out to show how university students accept and employ Mobile Learning Platform. In addition, it is asserted that behavioral models of technology acceptance are not equally applied in different cultures. The purpose of this study is to develop an extension of Technology Acceptance Model (TAM) by including four more constructs: namely, content quality, service quality, information quality and quality of the system. This is proposed to make it more relevant for the developing countries, like the United Arab Emirates (UAE). An online survey was carried out to obtain the data. A total of 221 students from the UAE took part in this survey. Structural equation modeling was used to determine and test the measurement and structural model. Data analysis was carried out, which showed that ten out of a total of 12 hypotheses are supported. This shows that there is support for the applicability of the extended TAM in the UAE. These outcomes suggest that Mobile Learning Platform should be considered by the policymakers and education developers as be-
\end{abstract}


ing not only a technological solution but also as being new e-learning platform especially for distance learning students.

Keywords-Mobile Learning Platform (MLP), United Arab Emirates, Technology Acceptance Model (TAM), System Quality, Information Quality, Content Quality, Service Quality, Structure equation modeling (PLS-SEM), Emirates universities.

\section{Introduction}

The number of studies that have been done to study the Mobile Learning Platform (MLP) within the academic context and discussing the applications and effectiveness of using such applications and their consequence on the applicants' intention to use such system is rarely discussed before [1]. While Mobile Learning (ML) has been widely used these days, investigating and acknowledging the main driving factors that increase the intention to use and adopt such method is essential [2]. A study conducted by [3] to find a proper answer to why some learners have a positive experience using Electronic Learning System (ELS),especially the mobile ones, while others have negative ones. The scholars used a set of dimensions to study such phenomenon which are behavioral intentions, learners' satisfaction, and Blackboard ELS effectiveness. Using a self-administrative survey from 424 university students, the study found that learners' satisfaction is influenced heavily by perceived self-efficacy in addition to perceived satisfaction and perceived usefulness which both affect learners' intention to use the ELS. To add more, the study denoted that ELS effectiveness can be enhanced by using a variety of means, such as interactive learning, multimedia instructions and even ELS quality. Based on this, studying the intention to use mobile learning platforms is a crucial part of ELS applications. Shultz (1980, p. 131 cited White, 1995), wrote: "I consider intention to refer to a mental state that guides and organizes behavior". Thus, intention to perform a behavior is considered by [4] as the key predictor of behavior. Studying the behaviour intention is important because the favorable behavior intention usually increase the customer loyalty especially the cognitive ones toward using and recommending the positive organization offerings from products and services [5]. If the intention is established right, then not just the frequency of use the ELS will be increased and twisting intention to behaviour will be an easy mission but also the willingness to recommend such systems will be highly happening [6].Large number of scholars went behind defining the main factors that affect electronic learning platforms use effectiveness. Some of these factors are: perceived ease of use, perceived usefulness, quality of the system, content quality and service quality, users' satisfaction, system quality, net benefits, learners' characteristics [3], [7]-[9]. However, not that much care was given to the mobile ones especially for the distance learners students [10], especially within the intention context. This study gives more lights on the main of them and such factors will be explained in more details. 


\section{Research Model and Hypotheses}

\subsection{System characteristics}

Quality of the system: Quality of systems might mean many things. [11] denoted that quality means is to perform well and does what is planned to do (output quality).A large number of scholars talks about the importance of system quality influence with respect to both ease of use and usefulness. A study by [12], for example, explains that system quality means many things, such as information quality, response time and system accessibility. While others, such as [13], [14] talked about web quality, information quality, and system quality. However, Davis et al. (1992) talked about output quality while [15] talked about the technical quality effect on online e-service acceptance.

Some scholars, such as [12], believed that ease of use and perceived usefulness are major functions of the quality of any system used especially through the Internet. The scholars discussed deeply why some users accept while other reject the website use through employing TAM. While the customers' acceptance is an important area that needs to be investigated to any applied systems, the scholars found that the website features are playing a critical role on users' acceptance and TAM fully mediate the usage behavior in the Internet environment. Moreover, [16] studied the positive and negative mediators of the system experience regarding computer playfulness and anxiety. The study found that system quality factors affect perceived ease of use especially for those service organizations which provide information about their products and services to users using any means, such as web portals. Such findings have been confirmed by other studies which denoted that system quality is an important element in providing organizations' services through other means, such as mobile commerce [17], mobile learning[18] and even mobile cloud services [19].

It has been claimed by many scholars, such as [20] that service quality significantly has a positive direct effect on information quality which in turn affect value, customer satisfaction and customer intention in service environments. To add more, [14] highlight the idea that perceived service quality is influenced directly by information presented on the web and such relationship has been confirmed by [21] who claimed that service quality is measured in most cases by information quality, especially when talks about both web-based learning systems adoption and post-purchase intention [22], or mobile use adoption [23]. Based on above explanations, three sub-hypotheses can be drawn as:

H1a: System Quality (SQ) of M-Learning Platforms has a significant positive effect on the perceived usefulness (PU) of M-Learning Platforms.

H1b: System Quality (SQ) of M-Learning Platforms has a significant positive effect on the perceived ease of use (PEOU) of M-Learning Platforms.

H1c: System Quality (SQ) significantly and directly affects information quality.

Information quality: There is an urgent need for organizations these days to enhance and improve their service quality especially those related to human and social parts [24], [25]. A large number of research papers, such as [26]-[28], have explained that enhancing service quality must be done through enhancing information quality 
provided. To add more, with the huge increase of Internet usage, there is a great opportunity for organizations to reach out billions of customers with very little cost especially using the mobile phone applications [29]. However, the information quality is still the dilemma. [12] conducted a study about understanding the behavioral intention to use a website. This study found that the users' acceptance is influenced mainly by the information quality provided by the website and the time that users' spends on waiting for the response. Another study [30] was about the extrinsic and intrinsic motivation to use computers in the workplace. It found that ease of use and quality are major functions of computer use and adoption in the workplace. Within the same stream, there is an increase in users' intention to use mobile services these days in all aspects of life and such needs are growing continuously because it increases users and consumers' performance [31].

Another study by [32] investigated the information quality of commercial website. The scholars mentioned that perceived information quality from consumers' side for organizations' offerings from products and services is critical and information quality is seen as the salient factors of predicting their decision behavior. Add on that, the study found that perceived usefulness, information quality and attitudes were significant indicators that enable predicting the customers' purchase behavior using the lodging Web sites. Moreover, online shopping is that part of research that is taking much of researchers' interest always. A study by [33] explained that the purchase intention is the products of some previous antecedents; mainly, the ease-of-use, perceived usefulness in addition to the trust in the e-vendor. Such antecedents are experienced important for behavior and repeat behavior especially for the online and mobile shopping and payments or learning [34]-[36]. Based on previous explanations, the hypotheses can be drawn as:

H2a: Information quality (IQ) of M-Learning Platforms has a significant positive effect on the perceived usefulness (PU) of M-Learning Platforms.

H2b: Information quality (IQ) of M-Learning Platforms has a significant positive effect on the perceived ease of use (PEOU) of M-Learning Platforms.

Content quality: It has been seen these days that there is an increase in using the Internet and their interrelated technologies and means, such as web-based applications and mobile applications in e-learning contexts. To enhance the e-learning effectiveness, there is a demand to enhance the quality of leaning environment. [37] clarified that learning environment consists of learning contents, learning management systems and interaction that offered by the e-learning systems. E-learning contents quality especially the information quality is taken much attention from scholars, such as [38], as core pre-requests of perceived ease of use and perceived usefulness.

A study by [32] investigated the effect of information quality to measure customers' behavioral intention to use lodging Web sites. The information quality has been studied through developing a model consists of three dimensions: information contents, perceived ease of use and perceived usefulness. The study found that the information quality model can be used as a useful framework to evaluate the information quality. Also, the study found that the information quality construct, attitude and perceived usefulness are significant indicators that help in predicting customers' purchase behavior especially through using lodging Websites. Within the same stream, 
[39] found that information quality help in users' perceived usefulness and perceived ease of use of mobile use especially within the e-learning course quality [40].

Another study by [41] about investigating the effect of playfulness on users' acceptance of online retailing with respect to Web quality. The study found that Web quality which have been categorized into a set of dimensions, which are service quality, information and system. They all have significant impacts on usefulness, perceived ease of use, playfulness which all in turn encouraged website users to use the website on the online retailing context. Based on this, large number of studies highlighted the importance of exerting much efforts on enhancing the quality of both e-platforms and m-platforms. Studies by [12], [42] claimed that both $\mathrm{m}$-service and e-service providers should emphasize the quality of the Website contents and the quality of information provided through mobile learning applications.

Regarding the online learning context, [13] highlighted the importance of improving the quality of the course provided through all platforms. Such enhancement increases the user's perceived web quality and even web page interactivity and web page downloaded. Both scholars claimed that if such enhancements happened for the online learning platforms, then the contents need to be learned will be seen as useful and ease to be used from learners. Based on above explanations, the content quality effect can be drawn as:

H3a: Content quality (CQ) of M-Learning Platforms has a significant positive effect on the perceived usefulness (PU) of M-Learning Platforms.

H3b: Content quality (CQ) of M-Learning Platforms has a significant positive effect on the perceived ease of use (PEOU) of M-Learning Platforms.

Service quality: In order to understand how both users and consumers perceive and evaluate mobile services provided especially the mobile payment ones, managers who work for organizations must understand how to deliver and evaluate providing superior service quality [43]-[46]. According to [47], perceived usefulness was defined as "the degree to which a person believes that using a particular system could enhance his or her job performance" and perceived ease of use can be described as "the degree to which a person believes that using a particular system is free of effort" (p.318). Based on such definitions and according to [48], The Technology Acceptance Model (TAM) denoted that both the perceived ease of use and the perceived usefulness of any information systems are seen as the key prerequisites of its use and the quality keys in relation to customer-centered services [49].

[50] Used a set of instruments to measure user perceived service quality of information that present through the Web portals. The study recommended that in order to enhance service quality of Web portals, portal managers should focus on a set of validated a five-dimension service quality instrument involving: usefulness of content, usability, accessibility, interaction and adequacy of information. Moreover, according to [51], service quality dimensions for online retailing stores are seen important. The main three dimensions, which are the perceived usefulness, perceived ease of use and user acceptance of information technology, replaying a critical role in the context of Internet commerce. Also, according to [14], information and system quality are considered major determinants of users perceived usefulness and perceived ease of use of any information presented on the web portals. Some scholars such as [52] studied a 
set of online service quality dimensions and found that the study sample was seen the perceived ease of use dimension more important than perceived usefulness dimension. Within the mobile use context, mobile perceived ease of use and mobile perceived usefulness are the major determinants of service provided through mobile platforms especially for mobile social learning platforms [53] and to have continuous intention to use mobile payments [44]. Based on the above explanations, the effect of service quality effect on both perceived usefulness and perceived ease of use can be drawn as:

H4a: Service quality (SRQ) of M-Learning Platforms has a significant positive effect on the perceived usefulness (PU) of M-Learning Platforms.

H4b: Service quality (SRQ) of M-Learning Platforms has a significant positive effect on the perceived ease of use (PEOU) of M-Learning Platforms.

\subsection{The technology acceptance model and User beliefs}

A large number of studies, such as [12], [54]-[61], have been conducted to investigate the effect of perceived ease of use and perceived usefulness on behavioral intention to use e-service delivered materials. However, a little number of studies have been done to investigate the effect of these constructs on the intention to use elearning materials delivered through MLP. The TAM model has been employed in this study to achieve such target.

The majority of studies have been done to investigate how service organizations use the Internet-delivered materials to users and a little number of these studies have taken the MLP ease of reuse effect on intention to use a specific e-service into deep analysis. A study executed by [62] to research the main positive and negative utilities that affect any system use and adoption. The study found that e-service adoption is influenced purely by performance perceived risk and such risk can be reduced by eservice perceived ease of use.[63] claimed that perceived ease of use is an important element in influencing the information technology use acceptance. Increase the acceptance level from users tends to increase the intention level of use and reuse of ELS. It has been found by [64] that perceived ease of use affect users' perception of computer systems. This idea is confirmed by [65] who found that perceived ease of use is seen as a fundamental element of Technology Acceptance, perception and even computer experience. One of the main issues that highlighted by many scholars, such as [66]-[69], are that perceived usefulness has a positive relation with behavioral intention, repeat use intention, use behavior and even reuse behavior. This idea is confirmed by [70] who mentioned that if users' perception of any system use is seen useful and easy to use then the acceptance and adoption level increase especially for the e-service, e-learning technology and mainly MLP.

One good example that provided by [71] who found the majority of e-materials delivered, such as governmental services (such as online voting and licenses renewal) participation and use, increase because of the users believing that such services are useful and easy to use. Also, the study found that trustworthiness, compatibility and perceived ease of use are the significant determinants of e-government service use and even create greater public access to information. However, other studies reached different results regarding the relationship between usefulness and intention to use. For 
example, [72] who studied the mobile banking adoption using the integration of TAM with respect to both perceived risk and perceived benefits. The scholars found that there was no direct relationship between perceived usefulness and intention to use and between perceived ease of use and attitude.

[73] Studied the relationship between perceived ease of use, perceived usefulness, and system use through applying the Structural Equation Modeling (SEM) through two studies. In the first study, the scholar found that perceived usefulness is an important part of determinants of system use while the second study confirmed the importance of both perceived ease of use and perceived usefulness on system use are essential to be achieved. To add more, previous research has proved that perceived ease of use is an important factor influencing user acceptance and usage behavior of information technologies. However, very little research has been conducted on understanding how such perception forms and changes over time. Also, according to [64], it has been found that perceived usefulness moderate the effect of ease of use and prior usage. Based on above explanation, the relationship effect of perceived ease of use, perceived usefulness and behavioral intention to reuse E-learning system can be drawn through following hypotheses:

H5: Perceived ease of use (PEOU) has a positive effect on the perceived usefulness (PU) of behavioural intention to use M-Learning Platforms.

H6: Perceived ease of use (PEOU) directly and significantly influences behavioral intention to use M-Learning Platforms.

H7: Perceived usefulness (PU) directly and significantly influences behavioral intention to use M-Learning Platforms.

The research model is put forward using these hypotheses, as shown in Figure 1. The theoretical model is converted into a structural equation model, which is then empirically examined.

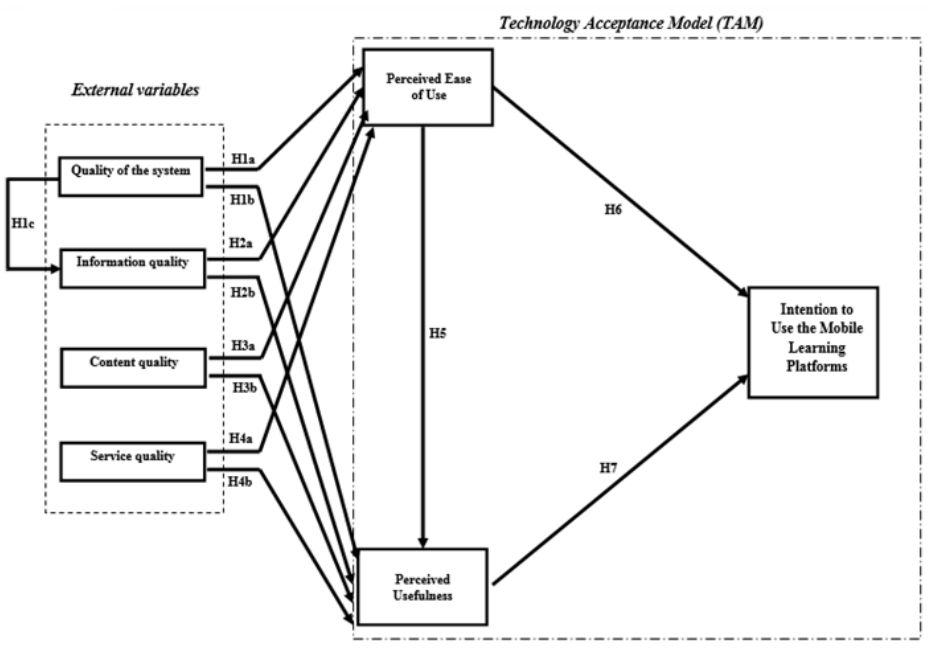

Fig. 1. The study model 


\section{$3 \quad$ Research Methodology}

\subsection{Sample and data collection}

Two very famous academic institutes operating in United Arab Emirates (UAE) who had implemented the Mobile Learning Platform (MLP) were selected for collecting samples. A total of 300 respondents participated in this online survey. These two universities were using two web-based M-learning systems, which were developed by two different M-learning platform/system providers. Both these M-learning platforms were developed and deployed almost 3 years ago and the students of these academic institutes were already using this M-learning system on a daily basis. This study was conducted with the help of Smart PLS Version 3.2.7 i.e. Structural equation modeling or SEM. This measurement model was evaluated with SEM and treated with final path model in the later stages. Table 1 is an in-depth illustration of the collected data. Of all the responses collected, there were 79 unfinished responses questionnaires which were wasted. We were left with 221 complete questionnaires that imply a response rate of $73.6 \%$. All in all, 221 responses containing valid responses contemplated and converted into a sample size as suggested by [74]. The estimated sampling size for a population of 300 is 169 respondents. These responses were then analyzed through the conceptual model. An analysis conducted using structural equation modeling is acceptable as a sample size; therefore, in our study, a sample size of 221 was much more than the insignificant requirements that were employed for testing the hypotheses [75]. It is essential to note that the stated hypotheses were based on current theories but were adopted in the context of E-learning.

Table 1. Participants details

\begin{tabular}{|l|c|}
\hline \multicolumn{1}{|c|}{ University } & No. of students \\
\hline The British University in Dubai (BUiD) & 130 \\
\hline University of Fujairah & 91 \\
\hline Total & 221 \\
\hline
\end{tabular}

\subsection{Study instrument}

As cited in this research, a survey instrument was devised and employed to test our hypothesis. Table 2 contains a list of the sources of the constructs used in the questionnaire. A total of twenty-six items were included in the survey with the aim of measuring the seven constructs in the questionnaire. To make this study more understandable and relatable some questions from previous studies were also included but after altering and adjusting them in accordance with our context.

Table 2. Constructs and their sources

\begin{tabular}{|l|c|l|}
\hline \multicolumn{1}{|c|}{ Constructs } & Number of items & \multicolumn{1}{c|}{ Source } \\
\hline Behavioral Intention to Use & 2 & {$[76]-[79]$} \\
\hline Content quality & 4 & {$[77],[79],[80]$} \\
\hline
\end{tabular}




\begin{tabular}{|l|l|l|}
\hline Information quality & 4 & {$[55],[81]-[83]$} \\
\hline Perceived Ease of Use & 4 & {$[76]-[78]$} \\
\hline Perceived Usefulness & 4 & {$[76]-[78],[81],[84]$} \\
\hline Quality of the system & 4 & {$[55],[78],[79],[81],[82],[85]$} \\
\hline Service quality & 4 & {$[55],[79],[81]-[83]$} \\
\hline
\end{tabular}

\subsection{Study instrument instrumentation}

After selecting some M-learning users and experts in the domain, a rigorous phase of pre-testing and pilot testing of measures was carried out. Table 3 presents the authenticated measures of this study. The questionnaire comprised of four items per construct, each of which was measured using a five-point Likert scale. These items ranged from "strongly disagree" to "strongly agree". The respondents, for every item, were required to circle the response that best described their level of agreement with the statements provided in the question. Moreover, the respondents were required to provide their basic demographic information as well.

\subsection{Pre-test of the questionnaire}

Two of the extremely well-known academic institutes, namely: University of Fujairah (UOF) and The British University in Dubai (BUiD) participated in the study and offered the target population comprising of a well-experienced group of $\mathrm{M}$ learning users. Using a $10 \%$ of the total sample size of the research survey (300 students), the sample size for the pilot study was selected in accordance with the standard research customs. Moreover, all the questions in the questionnaire were pre-tested using 30 students who were selected randomly. In addition, Cronbach's Alpha, according to [86], was employed for carrying out the reliability analysis for this study. The findings of the analysis show that the alpha values of all variables surpass 0.7 , as shown in Table 3. This implies that the final questionnaire is extremely reliable. The overall reliability and quality of the survey were enhanced ensuring that the respondents fully understood the final questionnaire.

Table 3. Cronbach's Alpha values for the pilot study (Cronbach's Alpha $\geq 0.70$ )

\begin{tabular}{|l|c|}
\hline \multicolumn{1}{|c|}{ Construct } & Cronbach's Alpha \\
\hline Behavioral Intention to Use & 0.733 \\
\hline Content quality & 0.713 \\
\hline Information quality & 0.813 \\
\hline Perceived Ease of Use & 0.844 \\
\hline Perceived Usefulness & 0.857 \\
\hline Quality of the system & 0.823 \\
\hline Service quality & 0.822 \\
\hline
\end{tabular}




\subsection{Pre-test of the questionnaire}

An in-depth account of the information about the respondents is provided in Table 4. All of the participants shared almost similar characteristics. Gender wise there were $118(53 \%)$ females and $103(47 \%)$ males. most of the participants they were between 18 and 29 years of age, with $47 \%$ from 30 to $39,39 \%$ from 40 to $49,11 \%$ from 50 to $59,3 \%$.

Table 4. Students' demographic data

\begin{tabular}{|c|c|c|c|}
\hline Variables & Answers & Frequency & Percentage $\%$ \\
\hline \multirow{2}{*}{ Gender } & Female & 118 & $53 \%$ \\
\hline & Male & 103 & $47 \%$ \\
\hline \multirow{4}{*}{ Age } & 18 to 29 & 104 & $47 \%$ \\
\hline & 30 to 39 & 87 & $39 \%$ \\
\hline & 40 to 49 & 24 & $11 \%$ \\
\hline & 50 to 59 & 6 & $3 \%$ \\
\hline \multirow{6}{*}{ College } & $\begin{array}{l}\text { College of Business and Econom- } \\
\text { ics }\end{array}$ & 66 & $30 \%$ \\
\hline & $\begin{array}{l}\text { College of Humanities and Social } \\
\text { Sciences }\end{array}$ & 12 & $6 \%$ \\
\hline & $\begin{array}{l}\text { College of Information Technolo- } \\
\text { gy }\end{array}$ & 87 & $39 \%$ \\
\hline & College of Engineering & 22 & $10 \%$ \\
\hline & College of Education & 34 & $15 \%$ \\
\hline & $\begin{array}{l}\text { College of Business and Econom- } \\
\text { ics }\end{array}$ & 66 & $30 \%$ \\
\hline \multirow{3}{*}{ Level of education } & Bachelor & 89 & $40 \%$ \\
\hline & Master & 84 & $38 \%$ \\
\hline & Doctorate & 48 & $22 \%$ \\
\hline
\end{tabular}

\section{$4 \quad$ Findings and Discussion}

The software used for this study is the Smart PLS for Partial Least Squares Structural Equation Modeling (PLS-SEM), which was developed by [87]. It is a very famous and widely used and readily available to academics and researchers. Moreover, this software has a very user-friendly interface and advanced reporting features. It is because of these features that the software's popularity has increased since its launch in 2005 [88]. the convergent validity and discriminate validity are two classes of validities that are generally employed for evaluating any measurement model [89]. The relationship between the indicators and latent construct that is being evaluated is defined by the measurement model [90].

\subsection{Data analysis}

The internal consistency of all the indicators in a relationship of any construct makes it possible to measure their Reliability. Therefore, in order to check the relia- 
bility of indicators, the Cronbach coefficient alpha [91] and the composite reliabilities coefficient [92] are used. Composite reliabilities are over the minimum acceptable limit of 0.70 [93]; [94].Table 5 presents the values of each coefficient as well as Cronbach coefficient alpha levels. All these values were above 0.70 , which is recommended for confirmatory research [95]. A two-stage methodology where the measurement model first is established and evaluated separately from the full structural equation model was used for the analysis of data [96]. For that reason, individual reliability for each item and the convergent and discriminate validity of the constructs was established as a preliminary step. The individual reliability for each item is provided by loadings or correlations between the item and the construct. The convergent validity per construct is suitable for a loading higher than 0.505 [97]. Table 8 points out that the loadings for every item are in total compliance with established conditions. Table 5 provides an account of the AVE scores attained for each of the seven constructs used. All of them surpass the minimum desirable value. In addition, the conjoint variance between the indicators and their construct is represented by the convergent validity, which is measured by the Average Variance Extracted (AVE).Moreover, the standard threshold for these values should be more than 0.50 [98].Table 6 provides the square roots of the AVE, indicated by bold numbers in the diagonal, and the correlation between constructs that highlight the acceptable discriminant validity of the measurements. The discriminant validity between constructs the AVE square root can be confirmed if they are greater than the correlation between constructs [98].

The analysis of the convergent and discriminant validity of the measurements was completed by analyzing the factor structure matrix of loadings and cross-loadings (Table 7). Items measuring the matching construct imply prominently and noticeably higher factor loadings on a single construct (bold numbers) as compared to other constructs. Once the individual reliability for every item and the convergent and discriminate validity of the constructs is recognized, the structural model is tested next. This also highlights the convergent and discriminate validity of the measurement. As per [99], the second condition of discriminant validity, is that the loading of every item must be higher as compared to the loading of its equivalent variable. Hence, it is evident from Table 8 that the second criterion has also been fulfilled. The third condition of discriminant validity is that the values of HTMT must be less than 0.85 . It is evident from Table 7 that the third criterion has also been confirmed; resulting in the fact that the discriminant validity has been established.

Table 5. Convergent validity results which assures acceptable values (Factor loading, Cronbach's Alpha, composite reliability $\geq 0.70 \&$ AVE $>0.5$ )

\begin{tabular}{|c|c|c|c|c|c|}
\hline Constructs & Items & Factor Loading & Cronbach's Alpha & $\mathbf{C R}$ & AVE \\
\hline \multirow{2}{*}{$\begin{array}{l}\text { Behavioral Intention to } \\
\text { Use }\end{array}$} & BI1 & 0.795 & \multirow{2}{*}{0.733} & \multirow{2}{*}{0.828} & \multirow{2}{*}{0.548} \\
\hline & $\mathrm{BI} 2$ & 0.822 & & & \\
\hline \multirow{4}{*}{ Content quality } & CQ1 & 0.768 & \multirow{4}{*}{0.713} & \multirow{4}{*}{0.823} & \multirow{4}{*}{0.537} \\
\hline & CQ2 & 0.766 & & & \\
\hline & CQ3 & 0.788 & & & \\
\hline & CQ4 & 0.707 & & & \\
\hline
\end{tabular}


Paper-Understanding the Quality Determinants that Influence the Intention to Use the Mobile Learning...

\begin{tabular}{|c|c|c|c|c|c|}
\hline \multirow{4}{*}{ Information quality } & IQ1 & 0.831 & \multirow{4}{*}{0.813} & \multirow{4}{*}{0.877} & \multirow{4}{*}{0.640} \\
\hline & IQ2 & 0.818 & & & \\
\hline & IQ3 & 0.748 & & & \\
\hline & IQ4 & 0.801 & & & \\
\hline \multirow{4}{*}{ Perceived Ease of Use } & PEOU1 & 0.738 & \multirow{4}{*}{0.844} & \multirow{4}{*}{0.895} & \multirow{4}{*}{0.683} \\
\hline & PEOU2 & 0.860 & & & \\
\hline & PEOU3 & 0.860 & & & \\
\hline & PEOU4 & 0.840 & & & \\
\hline \multirow{4}{*}{ Perceived Usefulness } & PU1 & 0.794 & \multirow{4}{*}{0.857} & \multirow{4}{*}{0.903} & \multirow{4}{*}{0.700} \\
\hline & PU2 & 0.861 & & & \\
\hline & PU3 & 0.849 & & & \\
\hline & PU4 & 0.842 & & & \\
\hline \multirow{4}{*}{ Quality of the system } & QS1 & 0.764 & \multirow{4}{*}{0.823} & \multirow{4}{*}{0.882} & \multirow{4}{*}{0.652} \\
\hline & QS2 & 0.811 & & & \\
\hline & QS3 & 0.826 & & & \\
\hline & QS4 & 0.828 & & & \\
\hline \multirow{4}{*}{ Service quality } & SRQ1 & 0.837 & \multirow{4}{*}{0.822} & \multirow{4}{*}{0.865} & \multirow{4}{*}{0.622} \\
\hline & SRQ2 & 0.880 & & & \\
\hline & SRQ3 & 0.850 & & & \\
\hline & SRQ4 & 0.839 & & & \\
\hline
\end{tabular}

Table 6. Fornell-Larcker Scale.

\begin{tabular}{|l|l|l|l|l|l|l|l|}
\hline & BI & CQ & IQ & PEOU & PU & QS & SRQ \\
\hline BI & $\mathbf{0 . 7 4 1}$ & & & & & & \\
\hline CQ & 0.468 & $\mathbf{0 . 7 3 3}$ & & & & & \\
\hline IQ & 0.748 & 0.439 & $\mathbf{0 . 8 0 0}$ & & & & \\
\hline PEOU & 0.656 & 0.359 & 0.650 & $\mathbf{0 . 8 2 6}$ & & & \\
\hline PU & 0.723 & 0.302 & 0.720 & 0.709 & $\mathbf{0 . 8 3 7}$ & & \\
\hline QS & 0.712 & 0.448 & 0.776 & 0.635 & 0.735 & $\mathbf{0 . 8 0 8}$ & \\
\hline SRQ & 0.554 & 0.344 & 0.453 & 0.546 & 0.404 & 0.584 & $\mathbf{0 . 7 8 9}$ \\
\hline
\end{tabular}

Table 7. Heterotrait-Monotrait Ratio (HTMT)

\begin{tabular}{|l|l|l|l|l|l|l|l|}
\hline & BI & CQ & IQ & PEOU & PU & QS & SRQ \\
\hline BI & & & & & & & \\
\hline CQ & 0.497 & & & & & & \\
\hline IQ & 0.657 & 0.569 & & & & & \\
\hline PEOU & 0.787 & 0.454 & 0.775 & & & & \\
\hline PU & 0.754 & 0.385 & 0.713 & 0.831 & & & \\
\hline QS & 0.555 & 0.574 & 0.743 & 0.750 & 0.770 & & \\
\hline SRQ & 0.082 & 0.081 & 0.105 & 0.093 & 0.193 & 0.091 & \\
\hline
\end{tabular}

Table 8. Cross-loading results

\begin{tabular}{|l|c|c|c|c|c|c|c|}
\hline & BI & CQ & IQ & PEOU & PU & QS & SRQ \\
\hline BI1 & 0.795 & 0.192 & 0.458 & 0.424 & 0.500 & 0.435 & 0.239 \\
\hline BI2 & 0.822 & 0.333 & 0.668 & 0.649 & 0.511 & 0.648 & 0.258 \\
\hline CQ1 & 0.275 & 0.768 & 0.346 & 0.305 & 0.197 & 0.310 & 0.204 \\
\hline CQ2 & 0.224 & 0.766 & 0.306 & 0.254 & 0.214 & 0.324 & 0.135 \\
\hline CQ3 & 0.233 & 0.788 & 0.280 & 0.200 & 0.237 & 0.271 & 0.220 \\
\hline
\end{tabular}




\begin{tabular}{|l|l|l|l|l|l|l|l|}
\hline CQ4 & 0.335 & 0.707 & 0.346 & 0.283 & 0.238 & 0.394 & 0.316 \\
\hline IQ1 & 0.229 & 0.375 & 0.831 & 0.577 & 0.627 & 0.688 & 0.461 \\
\hline IQ2 & 0.295 & 0.321 & 0.818 & 0.527 & 0.611 & 0.602 & 0.109 \\
\hline IQ3 & 0.302 & 0.287 & 0.748 & 0.376 & 0.494 & 0.579 & 0.373 \\
\hline IQ4 & 0.353 & 0.412 & 0.801 & 0.573 & 0.557 & 0.610 & 0.324 \\
\hline PEOU1 & 0.479 & 0.197 & 0.503 & 0.738 & 0.526 & 0.415 & 0.276 \\
\hline PEOU2 & 0.543 & 0.283 & 0.559 & 0.860 & 0.564 & 0.542 & 0.208 \\
\hline PEOU3 & 0.571 & 0.316 & 0.553 & 0.860 & 0.659 & 0.594 & 0.243 \\
\hline PEOU4 & 0.569 & 0.377 & 0.527 & 0.840 & 0.586 & 0.530 & 0.245 \\
\hline PU1 & 0.559 & 0.203 & 0.568 & 0.550 & 0.794 & 0.595 & 0.164 \\
\hline PU2 & 0.215 & 0.258 & 0.603 & 0.592 & 0.861 & 0.588 & 0.192 \\
\hline PU3 & 0.141 & 0.293 & 0.649 & 0.649 & 0.849 & 0.632 & 0.169 \\
\hline PU4 & 0.102 & 0.251 & 0.583 & 0.577 & 0.842 & 0.643 & 0.158 \\
\hline QS1 & 0.521 & 0.326 & 0.557 & 0.441 & 0.554 & 0.764 & 0.381 \\
\hline QS2 & 0.546 & 0.306 & 0.623 & 0.453 & 0.536 & 0.811 & 0.321 \\
\hline QS3 & 0.132 & 0.379 & 0.684 & 0.571 & 0.620 & 0.826 & 0.296 \\
\hline QS4 & 0.591 & 0.421 & 0.637 & 0.567 & 0.652 & 0.828 & 0.169 \\
\hline SRQ1 & 0.249 & 0.135 & 0.246 & 0.432 & 0.383 & 0.241 & 0.837 \\
\hline SRQ2 & 0.174 & 0.205 & 0.190 & 0.170 & 0.295 & 0.410 & 0.880 \\
\hline SRQ3 & 0.356 & 0.166 & 0.277 & 0.202 & 0.427 & 0.355 & 0.850 \\
\hline SRQ4 & 0.103 & 0.265 & 0.430 & 0.387 & 0.417 & 0.207 & 0.839 \\
\hline
\end{tabular}

\subsection{Coefficient of determination}

The structural model is commonly analyzed using the measure i.e. coefficient of determination, also known as R2 [100]. Moreover, the predictive accuracy of a model is checked with the help of this measure that is computed as the squared correlation between a particular endogenous construct's actual and predicted values [101]. Secondly, the coefficient of determination connotes the degree of variance in the endogenous constructs which are authenticated by all exogenous construct correlated to it. The resulting coefficient of determination where the value of R2value exceeds 0.67 is considered as high when the values range between 0.33 and $0.67 \mathrm{R} 2$ is considered as moderate, and the values between 0.19 and 0.33 are yield a weak R2 [102].

Table 9 shows that the R2 values for the Perceived Ease of Use and Behavioral Intention to Use ranged between 0.468 and 0.564 . Therefore, these constructs appear to have a Moderate predictive power. Moreover, the R2 value of the Perceived Usefulness is found to explain $68.5 \%$ of the variance, which means a high predictive power of this construct.

Table 9. $\mathrm{R}^{2}$ of the endogenous latent variables

\begin{tabular}{|l|c|l|}
\hline \multicolumn{1}{|c|}{ Constructs } & \multicolumn{1}{c|}{$\mathbf{R}^{\mathbf{2}}$} & \multicolumn{1}{c|}{ Results } \\
\hline Behavioral Intention to Use & 0.564 & Moderate \\
\hline Perceived Ease of Use & 0.468 & Moderate \\
\hline Perceived Usefulness & 0.685 & High \\
\hline
\end{tabular}

\subsection{Hypotheses testing}

According to [103]-[108] the outcomes of this study imply that the projected values of fit indices provide data fit for the structural model designed for this research model [109] (see Fig. 2). Moreover, the correlations between the hypotheses were 
analyzed with the help of the structural equation modeling and the resultant values can be seen in Table 10. Other than this, certain direct hypotheses also coincided with the prepositions made in this study [110]. It can be seen in the Table 10 that all the values met the provided range criteria. Figure 2 represents the resultant path coefficients for this proposed research model. Generally, the data supported ten out of twelve hypotheses. According to previous studies, all TAMs' constructs were verified in the model (PEOU, PU, and BI). Based on the data analysis hypotheses H1a, H1b, $\mathrm{H} 2 \mathrm{c}, \mathrm{H} 2 \mathrm{a}, \mathrm{H} 2 \mathrm{~b}, \mathrm{H} 3 \mathrm{~b}, \mathrm{H} 4 \mathrm{~b}, \mathrm{H} 5, \mathrm{H} 6$ and $\mathrm{H} 7$ were supported by the empirical data, while $\mathrm{H} 3 \mathrm{a}$ and $\mathrm{H} 4 \mathrm{a}$ were rejected. The results showed that PEOU significantly influenced PU $(\beta=0.353, \mathrm{P}<0.001)$ and $\mathrm{BI}(\beta=0.288, \mathrm{P}<0.001)$ supporting hypothesis H5 and $\mathrm{H} 6$ respectively. PU was determined to be significant in affecting BI $(\beta=0.519$, $\mathrm{P}<0.001$ ), supporting hypotheses $\mathrm{H} 7$.

Quality of the system, Information quality has significant effects on Perceived Ease of Use (PEOU) $(\beta=0.315, \mathrm{P}<0.001),(\beta=0.386, \mathrm{P}<0.001)$ respectively, but Content quality, Service quality has insignificant effects on Perceived Ease of Use (PEOU) $(\beta=0.048, \mathrm{P}=0.387),(\beta=0.012, \mathrm{P}=0.826)$, respectively; hence, H1a and $\mathrm{H} 2 \mathrm{a}$ are supported, but $\mathrm{H} 3 \mathrm{a}$ and $\mathrm{H} 4 \mathrm{a}$ are rejected. Quality of the system, Information quality, Content quality, and Service quality has also significant effects on Perceived Usefulness (PU) $(\beta=0.347, \mathrm{P}<0.001),(\beta=0.249, \mathrm{P}<0.001),(\beta=-0.090, \mathrm{P}<0.001),(\beta=-$ $0.138, \mathrm{P}<0.001)$, respectively; hence, $\mathrm{H} 1 \mathrm{~b}, \mathrm{H} 2 \mathrm{~b}, \mathrm{H} 3 \mathrm{~b}$, and $\mathrm{H} 4 \mathrm{~b}$ are supported. Finally, Quality of the system has significant effects on information quality $(\beta=0.777$, $\mathrm{P}<0.001$ ) then, H1c is supported.

Table 10. Results of structural Model - Research Hypotheses Significant at $\mathrm{p}^{* *}=<0.01, \mathrm{p}^{*}<0.05$ Significant at $\left.\mathrm{p}^{* *}=<0.01, \mathrm{p}^{*}<0.05\right)$.

\begin{tabular}{|c|c|c|c|c|c|c|}
\hline $\mathbf{H}$ & Relationship & Path & $t$-value & $p$-value & Direction & Decision \\
\hline H1a & $\begin{array}{l}\text { Quality of the system -> } \\
\text { Perceived Ease of Use }\end{array}$ & 0.315 & 3.739 & 0.000 & Positive & Supported** \\
\hline H1b & $\begin{array}{l}\text { Quality of the system -> } \\
\text { Perceived Usefulness }\end{array}$ & 0.347 & 4.301 & 0.000 & Positive & Supported** \\
\hline H1c & $\begin{array}{l}\text { Quality of the system -> } \\
\text { Information quality }\end{array}$ & 0.777 & 21.009 & 0.000 & Positive & Supported** \\
\hline $\mathrm{H} 2 \mathbf{a}$ & $\begin{array}{l}\text { Information quality -> } \\
\text { Perceived Ease of Use }\end{array}$ & 0.386 & 4.130 & 0.000 & Positive & Supported** \\
\hline H2b & $\begin{array}{l}\text { Information quality -> } \\
\text { Perceived Usefulness }\end{array}$ & 0.249 & 3.183 & 0.002 & Positive & Supported** \\
\hline H3a & $\begin{array}{l}\text { Content quality }->\text { Per- } \\
\text { ceived Ease of Use }\end{array}$ & 0.048 & 0.866 & 0.387 & Positive & Not supported \\
\hline H3b & $\begin{array}{l}\text { Content quality -> Per- } \\
\text { ceived Usefulness }\end{array}$ & -0.090 & 2.109 & 0.035 & Negative & Supported* \\
\hline $\mathbf{H 4 a}$ & $\begin{array}{l}\text { Service quality -> Per- } \\
\text { ceived Ease of Use }\end{array}$ & 0.012 & 0.220 & 0.826 & Positive & Not supported \\
\hline H4b & $\begin{array}{l}\text { Service quality -> Per- } \\
\text { ceived Usefulness }\end{array}$ & -0.138 & 3.598 & 0.000 & Negative & Supported $* *$ \\
\hline H5 & $\begin{array}{l}\text { Perceived Ease of Use -> } \\
\text { Perceived Usefulness }\end{array}$ & 0.353 & 5.231 & 0.000 & Positive & Supported** \\
\hline H6 & $\begin{array}{l}\text { Perceived Ease of Use -> } \\
\text { Behavioral Intention to Use }\end{array}$ & 0.288 & 3.586 & 0.000 & Positive & Supported** \\
\hline H7 & $\begin{array}{l}\text { Perceived Usefulness -> } \\
\text { Behavioral Intention to Use }\end{array}$ & 0.519 & 7.108 & 0.000 & Positive & Supported $* *$ \\
\hline
\end{tabular}




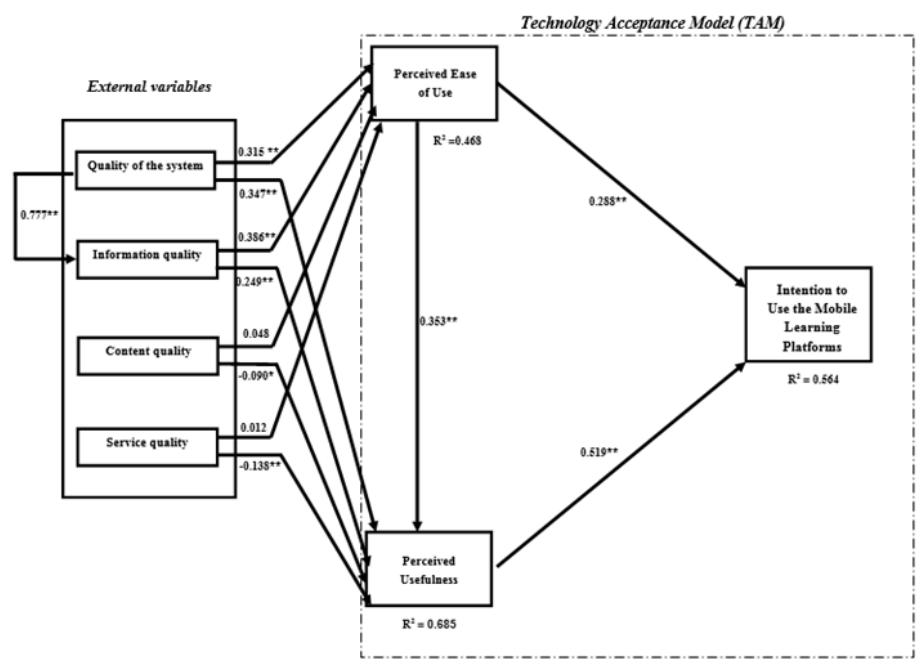

Fig. 2. Path coefficient results (significant at $\mathrm{p}^{* *}<=0.01, \mathrm{p}^{*}<0.05$ ).

\section{Conclusion and Future Works}

\subsection{Study contributions and discussion}

This study seeks to assess how quality features have an impact on students' beliefs with respect to acceptance of mobile learning on the basis of extending Technology Acceptance Model (TAM). Sample data was obtained from two private universities in the UAE that have good academic reputations. The survey involved randomly circulating 300 questionnaires, out of which 221 completed questionnaires were examined. Hence, the usable response rate was $73.6 \%$. It is shown in the findings that the Mobile Learning Platforms' infrastructure, i.e. (Quality of the system, content quality, Information quality, and service quality) directly affects perceived usefulness of mobile learning and ease of use, which positively influences intention to use the Mobile Learning Platforms [77], [78], [111]-[113]. On the basis of our model and structural equations, it can be asserted that one of the ways success of Mobile Learning Platforms in an enterprise can be measured is system quality, which has a direct effect on the intention of user and use of the system, subsequently influencing how these systems are successful. Therefore, when there is high system quality of Mobile Learning Platforms, user intention and the actual use of the system is also greater [114]. The proposed research model was strongly supported by the analysis. The findings of the researchers such as [55], [77], [78], [81], [103], [111]-[113], [115]-[120] and our results have similarities. During the implementation of Mobile Learning Platforms, an important concern for managers and executives has perceived usefulness. It was indicated in the results that the adoption of Mobile Learning Platforms has significant and direct effects on university students [77], [112]; [121]. User friendliness and ease of 
use of the system should be fully exploited by educators and system designers so that user intention and system use increases with respect to mobile learning systems. The success of mobile learning systems increases because of higher user intention and higher use of the system. Because user intention directly impacts the advantages of using the system, greater benefits will be observed. The content, services and information of the mobile learning system should be fully exploited by instructional designers, in addition to using tests and monitoring the progress of participants so that the advantages of utilizing the system can be maximized. When there is greater use of a mobile learning system, then there will also be an increase in intention (direct effect). Therefore, because of this direct effect of system use on user intention, there is an impact on the effectiveness of the systems. The study results showed that there was statistically significant association between use of the system and user intention. There has been extensive development in the UAE in the past few years, with significant improvement in mobile telecommunication infrastructures because of the staunch dedication of the UAE government. The national mobile learning strategy is implemented according to the wishes of the UAE government, it has emphasized on the significance of mobile learning and has stressed on the need to have wider application of the project in the UAE. This calls for more research in this domain so that students are motivated to adopt mobile learning in higher education. It will possibly enhance the country's reputation and generate competitive edge in the field of higher education in the UAE. This study was based on this aspiration so that the factors that influence the students' acceptance of mobile learning in Emirates universities could be determined. There are critical implications in the ultimate findings for university administrators and system developers, and this may offer a vivid explanation on how quality features influence the beliefs of students regarding acceptance of Mobile Learning Platforms on the basis of a hybrid model of quality features and TAM. This would hence, stress on the most significant directions to create high quality of Mobile Learning Platforms.

\subsection{Limitations and future directions}

There are certain limitations of this study, such as it is based on a single Mobile Learning Platform (MLP). The findings can also be a bit restrictive because the use of a purposive sampling approach urged that the data be collected from two universities. For further research, an evaluation of the influence of the three significant external variables: namely, system quality perceived self-efficacy and facilitating conditions on acceptance and usage behavior of different populations and different Mobile Learning Platform (MLP) is strongly suggested.

\subsection{Implications}

The basis of the study is the TAM Model, and its objective is to include new variables in the model, i.e. quality of the system, content quality, information quality and service quality so that the students' behavioral intention to employ mobile learning platforms in the UAE can be evaluated. It was found in the study that there is a wide 
acceptance of mobile learning in the UAE. Support was shown for ten out of the twelve hypothesized relationships between the exogenous and endogenous constructs. The outcomes of this study suggest that the system quality happens to be a robust factor that significantly impacts a students' use of the mobile learning system. For that matter, it is important that the mobile learning system designers and university policymakers must pay attention to improve the quality of mobile learning system as well as other features like user-friendliness, easy accessibility and reliability should also be improved. Better quality can only be maintained if a constant quality improvement process is devised to collect feedback from the users of the mobile learning system. The concerns raised about the quality as well as the problems encountered by the users and their commendations for improvement should be considered. Hence, the improvement actions directed towards the mobile learning system should be designed in view of that. Moreover, ensuring that universities from time to time collect information from mobile learning system users regarding experiences with mobile learning system usage, is extremely important in this regard.

\section{References}

[1] S. Y. Park, "An analysis of the technology acceptance model in understanding university students' behavioral intention to use e-learning," J. Educ. Technol. Soc., vol. 12, no. 3, p. 150, 2009.

[2] Liu, H. Li, and C. Carlsson, "Factors driving the adoption of m-learning: An empirical study," Comput. Educ., vol. 55, no. 3, pp. 1211-1219, 2010. https://doi.org/10.1016/j.com pedu.2010.05.018

[3] S.-S. Liaw, "Investigating students' perceived satisfaction, behavioral intention, and effectiveness of e-learning: A case study of the Blackboard system," Comput. Educ., vol. 51, no. 2, pp. 864-873, 2008. https://doi.org/10.1016/j.compedu.2007.09.005

[4] F. Seyfi, K. C. Poudel, J. Yasuoka, K. Otsuka, and M. Jimba, "Intention to seek professional psychological help among college students in Turkey: influence of help-seeking attitudes," BMC Res. Notes, vol. 6, no. 1, p. 519, 2013. https://doi.org/10.1186/17 $\underline{56-0500-6-519}$

[5] C.-F. Chen and F.-S. Chen, "Experience quality, perceived value, satisfaction and behavioral intentions for heritage tourists," Tour. Manag., vol. 31, no. 1, pp. 29-35, 2010. https://doi.org/10.1016/j.tourman.2009.02.008

[6] C.-F. Chen, "Investigating structural relationships between service quality, perceived value, satisfaction, and behavioral intentions for air passengers: Evidence from Taiwan," Transp. Res. Part A Policy Pract., vol. 42, no. 4, pp. 709-717, 2008. https://doi.org/10.101 6/j.tra.2008.01.007

[7] R. D. Freeze, K. A. Alshare, P. L. Lane, and H. J. Wen, "IS success model in e-learning context based on students' perceptions," J. Inf. Syst. Educ., vol. 21, no. 2, p. 173, 2010.

[8] P. Pocatilu, F. Alecu, and M. Vetrici, "Using cloud computing for E-learning systems," in Proceedings of the 8th WSEAS international conference on Data networks, communications, computers, 2009, pp. 54-59.

[9] Y.-S. Wang, H.-Y. Wang, and D. Y. Shee, "Measuring e-learning systems success in an organizational context: Scale development and validation," Comput. Human Behav., vol. 23, no. 4, pp. 1792-1808, 2007. https://doi.org/10.1016/i.chb.2005.10.006 
[10] M. J. W. Lee and A. Chan, "Pervasive, lifestyle-integrated mobile learning for distance learners: an analysis and unexpected results from a podcasting study," Open Learn., vol. 22, no. 3, pp. 201-218, 2007. https://doi.org/10.1080/02680510701619810

[11] V. Venkatesh and F. D. Davis, "A theoretical extension of the technology acceptance model: Four longitudinal field studies," Manage. Sci., vol. 46, no. 2, pp. 186-204, 2000. https://doi.org/10.1287/mnsc.46.2.186.11926

[12] J. C.-C. Lin and H. Lu, "Towards an understanding of the behavioural intention to use a web site,” Int. J. Inf. Manage., vol. 20, no. 3, pp. 197-208, 2000.

[13] A. M. Aladwani and P. C. Palvia, "Developing and validating an instrument for measuring user-perceived web quality," Inf. Manag., vol. 39, no. 6, pp. 467-476, 2002. https://doi.org/10.1016/s0378-7206(01)00113-6

[14] Z. Yang, S. Cai, Z. Zhou, and N. Zhou, "Development and validation of an instrument to measure user perceived service quality of information presenting web portals," Inf. Manag., vol. 42, no. 4, pp. 575-589, 2005. https://doi.org/10.1016/j.im.2004.03.001

[15] T. Pikkarainen, K. Pikkarainen, H. Karjaluoto, and S. Pahnila, "Consumer acceptance of online banking: an extension of the technology acceptance model," Internet Res., vol. 14, no. 3, pp. 224-235, 2004. https://doi.org/10.1108/10662240410542652

[16] G. Hackbarth, V. Grover, and Y. Y. Mun, "Computer playfulness and anxiety: positive and negative mediators of the system experience effect on perceived ease of use," Inf. Manag., vol. 40, no. 3, pp. 221-232, 2003. https://doi.org/10.1016/s0378-7206(02)00006-x

[17] C.-C. Lee, H. K. Cheng, and H.-H. Cheng, "An empirical study of mobile commerce in insurance industry: Task-technology fit and individual differences," Decis. Support Syst., vol. 43, no. 1, pp. 95-110, 2007. https://doi.org/10.1016/j.dss.2005.05.008

[18] D. Parsons and H. Ryu, "A framework for assessing the quality of mobile learning," in Proceedings of the International Conference for Process Improvement, Research and Education, 2006, pp. 17-27.

[19] E. Park and K. J. Kim, "An integrated adoption model of mobile cloud services: exploration of key determinants and extension of technology acceptance model," Telemat. Informatics, vol. 31, no. 3, pp. 376-385, 2014. https://doi.org/10.1016/j.tele.2013.11.008

[20] J. J. Cronin Jr, M. K. Brady, and G. T. M. Hult, "Assessing the effects of quality, value, and customer satisfaction on consumer behavioral intentions in service environments," J. Retail., vol. 76, no. 2, pp. 193-218, 2000. https://doi.org/10.1016/s0022-4359(00)00028-2

[21] W.-T. Wang and C.-C. Wang, "An empirical study of instructor adoption of web-based learning systems,” Comput. Educ., vol. 53, no. 3, pp. 761-774, 2009.

[22] Y.-F. Kuo, C.-M. Wu, and W.-J. Deng, "The relationships among service quality, perceived value, customer satisfaction, and post-purchase intention in mobile value-added services," Comput. Human Behav., vol. 25, no. 4, pp. 887-896, 2009. https://doi.org/10.10 16/j.chb.2009.03.003

[23] H.-F. Lin, "An empirical investigation of mobile banking adoption: The effect of innovation attributes and knowledge-based trust," Int. J. Inf. Manage., vol. 31, no. 3, pp. 252260, 2011. https://doi.org/10.1016/j.ijinfomgt.2010.07.006

[24] P. Legris, J. Ingham, and P. Collerette, "Why do people use information technology? A critical review of the technology acceptance model," Inf. Manag., vol. 40, no. 3, pp. 191204, 2003. https://doi.org/10.1016/s0378-7206(01)00143-4

[25] G. Ammari, B. Alkurdi, A. Alshurideh, and A. Alrowwad, "Investigating the impact of communication satisfaction on organizational commitment: a practical approach to increase employees' loyalty,” Int. J. Mark. Stud., vol. 9, no. 2, pp. 113-133, 2017. https://doi.org/10.5539/ijms.v9n2p113 
[26] V. Grover, M. J. Cheon, and J. T. C. Teng, "The effect of service quality and partnership on the outsourcing of information systems functions," J. Manag. Inf. Syst., vol. 12, no. 4, pp. 89-116, 1996.

[27] W. J. Kettinger and C. C. Lee, "Pragmatic perspectives on the measurement of information systems service quality,” Mis Q., pp. 223-240, 1997. https://doi.org/10.2307/249421

[28] R. T. Watson, L. F. Pitt, and C. B. Kavan, "Measuring information systems service quality: lessons from two longitudinal case studies," MIS Q., pp. 61-79, 1998. https://doi.org/10.2307/249678

[29] K. Siau, L. Ee-Peng, and Z. Shen, "Mobile commerce: promises, challenges, and research agenda,” J. Database Manag., vol. 12, no. 3, p. 4, 2001. https://doi.org/10.4018/jdm.20010 $\underline{70101}$

[30] F. D. Davis, R. P. Bagozzi, and P. R. Warshaw, "Extrinsic and intrinsic motivation to use computers in the workplace,” J. Appl. Soc. Psychol., vol. 22, no. 14, pp. 1111-1132, 1992. https://doi.org/10.1111/j.1559-1816.1992.tb00945.x

[31] H. Nysveen, P. E. Pedersen, and H. Thorbjørnsen, "Intentions to use mobile services: Antecedents and cross-service comparisons," J. Acad. Mark. Sci., vol. 33, no. 3, p. 330, 2005.

[32] M. Jeong and C. U. Lambert, "Adaptation of an information quality framework to measure customers' behavioral intentions to use lodging Web sites," Int. J. Hosp. Manag., vol. 20, no. 2, pp. 129-146, 2001. https://doi.org/10.1016/s0278-4319(00)00041-4

[33] D. Gefen, E. Karahanna, and D. W. Straub, "Trust and TAM in online shopping: An integrated model," MIS Q., vol. 27, no. 1, pp. 51-90, 2003. https://doi.org/10.2307/30036519

[34] J.-H. Wu and S.-C. Wang, "What drives mobile commerce?: An empirical evaluation of the revised technology acceptance model," Inf. Manag., vol. 42, no. 5, pp. 719-729, 2005.

[35] Y.-M. Huang, Y.-M. Huang, S.-H. Huang, and Y.-T. Lin, "A ubiquitous English vocabulary learning system: Evidence of active/passive attitudes vs. usefulness/ease-of-use," Comput. Educ., vol. 58, no. 1, pp. 273-282, 2012. https://doi.org/10.1016/j.compedu. $\underline{2011.08 .008}$

[36] S. Ma, D. G. Steger, P. E. Doolittle, and A. C. Stewart, "Improved Academic Performance and Student Perceptions of Learning Through Use of a Cell Phone-Based Personal Response System," J. Food Sci. Educ., vol. 17, no. 1, pp. 27-32, 2018. https://doi.org/10. $1111 / 1541-4329.12131$

[37] J.-K. Lee and W.-K. Lee, "The relationship of e-Learner's self-regulatory efficacy and perception of e-Learning environmental quality," Comput. Human Behav., vol. 24, no. 1, pp. 32-47, 2008. https://doi.org/10.1016/j.chb.2006.12.001

[38] T. Ahn, S. Ryu, and I. Han, "The impact of the online and offline features on the user acceptance of Internet shopping malls," Electron. Commer. Res. Appl., vol. 3, no. 4, pp. 405-420, 2004. https://doi.org/10.1016/j.elerap.2004.05.001

[39] M. C. tom Dieck and T. Jung, "A theoretical model of mobile augmented reality acceptance in urban heritage tourism," Curr. Issues Tour., vol. 21, no. 2, pp. 154-174, 2018. https://doi.org/10.1080/13683500.2015.1070801

[40] J. K. Law, P. A. Thome, B. Lindeman, D. C. Jackson, and A. O. Lidor, "Student use and perceptions of mobile technology in clinical clerkships-Guidance for curriculum design," Am. J. Surg., vol. 215, no. 1, pp. 196-199, 2018. https://doi.org/10.1016/j.amjsurg.2017.0 $\underline{1.038}$

[41] T. Ahn, S. Ryu, and I. Han, "The impact of Web quality and playfulness on user acceptance of online retailing," Inf. Manag., vol. 44, no. 3, pp. 263-275, 2007. https://doi. org/10.1016/j.im.2006.12.008

[42] N. Parsazadeh, R. Ali, and M. Rezaei, "A framework for cooperative and interactive mobile learning to improve online information evaluation skills," Comput. Educ., vol. 120, pp. 75-89, 2018. https://doi.org/10.1016/j.compedu.2018.01.010 
[43] V. A. Zeithaml, A. Parasuraman, and A. Malhotra, "Service quality delivery through web sites: a critical review of extant knowledge," J. Acad. Mark. Sci., vol. 30, no. 4, p. 362, 2002. https://doi.org/10.1177/009207002236911

[44] M.-C. Tsai, Y.-Y. Chien, and C.-C. Cheng, "Upgrading service quality of mobile banking," Int. J. Mob. Commun., vol. 16, no. 1, pp. 82-115, 2018.

[45] M. Alshurideh, "The Factors Predicting Students' Satisfaction with Universities' Healthcare Clinics' Services: A Case-Study from the Jordanian Higher Education Sector," Dirasat Adm. Sci., vol. 41, no. 2, pp. 451-464, 2014. https://doi.org/10.12816/0007482

[46] M. T. Alshurideh, “The Impact Of Islamic Bank’s Service Quality Perception On Jordanian Customer's Loyalty,” Jounal Manag. reseach, vol. 9, 2017.

[47] R. Saadé and B. Bahli, "The impact of cognitive absorption on perceived usefulness and perceived ease of use in on-line learning: an extension of the technology acceptance model,” Inf. Manag., vol. 42, no. 2, pp. 317-327, 2005. https://doi.org/10.1016/j.im.2003.1 $\underline{2.013}$

[48] D. Gefen and M. Keil, "The impact of developer responsiveness on perceptions of usefulness and ease of use: an extension of the technology acceptance model," ACM SIGMIS Database DATABASE Adv. Inf. Syst., vol. 29, no. 2, pp. 35-49, 1998. https://do i.org/10.1145/298752.298757

[49] Z. Yang, M. Jun, and R. T. Peterson, "Measuring customer perceived online service quality: scale development and managerial implications," Int. J. Oper. Prod. Manag., vol. 24, no. 11, pp. 1149-1174, 2004. https://doi.org/10.1108/01443570410563278

[50] K. C. C. Yang, "Exploring factors affecting the adoption of mobile commerce in Singapore," Telemat. informatics, vol. 22, no. 3, pp. 257-277, 2005. https://doi.org/10.101 6/j.tele.2004.11.003

[51] Z. Yang and M. Jun, "Consumer perception of e-service quality: from internet purchaser and non-purchaser perspectives," J. Bus. Strateg., vol. 19, no. 1, p. 19, 2002.

[52] Z. Yang and X. Fang, "Online service quality dimensions and their relationships with satisfaction: A content analysis of customer reviews of securities brokerage services," Int. J. Serv. Ind. Manag., vol. 15, no. 3, pp. 302-326, 2004. https://doi.org/10.1108/095642304 10540953

[53] K.-B. Ooi, J.-J. Hew, and V.-H. Lee, "Could the mobile and social perspectives of mobile social learning platforms motivate learners to learn continuously?," Comput. Educ., vol. 120, pp. 127-145, 2018. https://doi.org/10.1016/j.compedu.2018.01.017

[54] C.-L. Hsu and H.-P. Lu, "Why do people play on-line games? An extended TAM with social influences and flow experience," Inf. Manag., vol. 41, no. 7, pp. 853-868, 2004. https://doi.org/10.1016/j.im.2003.08.014

[55] J. C. Roca, C.-M. Chiu, and F. J. Martínez, "Understanding e-learning continuance intention: An extension of the Technology Acceptance Model," Int. J. Hum. Comput. Stud., vol. 64, no. 8, pp. 683-696, 2006.

[56] A. V Hausman and J. S. Siekpe, "The effect of web interface features on consumer online purchase intentions," J. Bus. Res., vol. 62, no. 1, pp. 5-13, 2009. https://doi.org/10.1016/j.j busres.2008.01.018

[57] S. Alharbi and S. Drew, "Using the technology acceptance model in understanding academics' behavioural intention to use learning management systems," Int. J. Adv. Comput. Sci. Appl., vol. 5, no. 1, pp. 143-155, 2014.

[58] M. S. Khairi and Z. Baridwan, "An empirical study on organizational acceptance accounting information systems in Sharia banking," Int. J. Account. Bus. Soc., vol. 23, no. 1, pp. 97-122, 2015.

[59] C. Yoon, "Extending the TAM for Green IT: A normative perspective," Comput. Human Behav., vol. 83, pp. 129-139, 2018. 
[60] P. Ifinedo, J. Pyke, and A. Anwar, "Business undergraduates' perceived use outcomes of Moodle in a blended learning environment: The roles of usability factors and external support," Telemat. Informatics, vol. 35, no. 1, pp. 93-102, 2018. https://doi.org/10.1016/j. tele.2017.10.001

[61] T. Natarajan, S. A. Balasubramanian, and D. L. Kasilingam, "The moderating role of device type and age of users on the intention to use mobile shopping applications," Technol. Soc., 2018. https://doi.org/10.1016/j.techsoc.2018.01.003

[62] M. S. Featherman and P. A. Pavlou, "Predicting e-services adoption: a perceived risk facets perspective," Int. J. Hum. Comput. Stud., vol. 59, no. 4, pp. 451-474, 2003. https://doi.org/10.1016/s1071-5819(03)00111-3

[63] V. Venkatesh, "Determinants of perceived ease of use: Integrating control, intrinsic motivation, and emotion into the technology acceptance model," Inf. Syst. Res., vol. 11, no. 4, pp. 342-365, 2000. https://doi.org/10.1287/isre.11.4.342.11872

[64] K. Amoako-Gyampah, "Perceived usefulness, user involvement and behavioral intention: an empirical study of ERP implementation," Comput. Human Behav., vol. 23, no. 3, pp. 1232-1248, 2007. https://doi.org/10.1016/j.chb.2004.12.002

[65] P. Guriting and N. Oly Ndubisi, "Borneo online banking: evaluating customer perceptions and behavioural intention," Manag. Res. news, vol. 29, no. 1/2, pp. 6-15, 2006. https://doi. org/10.1108/01409170610645402

[66] I. Mălăescu and S. G. Sutton, "The effects of decision aid structural restrictiveness on cognitive load, perceived usefulness, and reuse intentions,” Int. J. Account. Inf. Syst., vol. 17, pp. 16-36, 2015. https://doi.org/10.1016/j.accinf.2014.02.001

[67] H. Lin and Z. Chen, "Influence of SMS advertising on consumer behavioral intention," J. Organ. End User Comput., vol. 27, no. 4, pp. 25-42, 2015. https://doi.org/10.4018/joeuc. 2015100102

[68] H. Son, S. Lee, and C. Kim, "What drives the adoption of building information modeling in design organizations? An empirical investigation of the antecedents affecting architects' behavioral intentions," Autom. Constr., vol. 49, pp. 92-99, 2015. https://doi.org/10.1016/j. autcon.2014.10.012

[69] S. Joo, S. Kim, and Y. Kim, "An exploratory study of health scientists' data reuse behaviors: Examining attitudinal, social, and resource factors,” Aslib J. Inf. Manag., vol. 69, no. 4, pp. 389-407, 2017. https://doi.org/10.1108/ajim-12-2016-0201

[70] S.-H. Liu, H.-L. Liao, and J. A. Pratt, "Impact of media richness and flow on e-learning technology acceptance," Comput. Educ., vol. 52, no. 3, pp. 599-607, 2009. https://doi.org/ 10.1016/j.compedu.2008.11.002

[71] L. Carter and F. Bélanger, "The utilization of e-government services: citizen trust, innovation and acceptance factors," Inf. Syst. J., vol. 15, no. 1, pp. 5-25, 2005. https://doi.org/10.1111/j.1365-2575.2005.00183.x

[72] U. Akturan and N. Tezcan, "Mobile banking adoption of the youth market: Perceptions and intentions," Mark. Intell. Plan., vol. 30, no. 4, pp. 444-459, 2012. https://doi.org/10.11 $\underline{08 / 02634501211231928}$

[73] D. A. Adams, R. R. Nelson, and P. A. Todd, "Perceived usefulness, ease of use, and usage of information technology: A replication,” MIS Q., pp. 227-247, 1992. https://doi.org/10. $2307 / 249577$

[74] R. V Krejcie and D. W. Morgan, "Determining sample size for research activities," Educ. Psychol. Meas., vol. 30, no. 3, pp. 607-610, 1970.

[75] C. L. Chuan and J. Penyelidikan, "Sample size estimation using Krejcie and Morgan and Cohen statistical power analysis: A comparison," J. Penyelid. IPBL, vol. 7, pp. 78-86, 2006. 
[76] C.-T. Chang, J. Hajiyev, and C.-R. Su, "Examining the students' behavioral intention to use e-learning in Azerbaijan? The General Extended Technology Acceptance Model for Elearning approach,” Comput. Educ., vol. 111, pp. 128-143, 2017. https://doi.org/10.1016/j. compedu.2017.04.010

[77] B. Rym, B. Olfa, and B. M. Mélika, "Determinants of e-learning acceptance: An empirical study in the Tunisian context," Am. J. Ind. Bus. Manag., vol. 3, no. 3, p. 307, 2013. https://doi.org/10.4236/ajibm.2013.33036

[78] N. Fathema, D. Shannon, and M. Ross, "Expanding The Technology Acceptance Model (TAM) to Examine Faculty Use of Learning Management Systems (LMSs) In Higher Education Institutions.," J. Online Learn. Teach., vol. 11, no. 2, 2015.

[79] Y. Cheng, “Antecedents and consequences of e-learning acceptance,” Inf. Syst. J., vol. 21, no. 3, pp. 269-299, 2011.

[80] M. A. Almaiah, M. A. Jalil, and M. Man, "Extending the TAM to examine the effects of quality features on mobile learning acceptance," J. Comput. Educ., vol. 3, no. 4, pp. 453485, 2016. https://doi.org/10.1007/s40692-016-0074-1

[81] A. Y. Alsabawy, A. Cater-Steel, and J. Soar, "Determinants of perceived usefulness of elearning systems," Comput. Human Behav., vol. 64, pp. 843-858, 2016. https://doi.org/10. 1016/j.chb.2016.07.065

[82] M. Aparicio, F. Bacao, and T. Oliveira, "Grit in the path to e-learning success," Comput. Human Behav., vol. 66, pp. 388-399, 2017. https://doi.org/10.1016/j.chb.2016.10.009

[83] H. Mohammadi, "Investigating users' perspectives on e-learning: An integration of TAM and IS success model," Comput. Human Behav., vol. 45, pp. 359-374, 2015. https://doi.org/10.1016/i.chb.2014.07.044

[84] S. A. Salloum and K. Shaalan, "Adoption of E-Book for University Students," in International Conference on Advanced Intelligent Systems and Informatics, 2018, pp. 481-494. https://doi.org/10.1007/978-3-319-99010-1 44

[85] U. Marjanovic, M. Delić, and B. Lalic, "Developing a model to assess the success of elearning systems: evidence from a manufacturing company in transitional economy," Inf. Syst. E-bus. Manag., vol. 14, no. 2, pp. 253-272, 2016. https://doi.org/10.1007/s10257$\underline{015-0282-7}$

[86] R. L. Hair, J., Black, W. C., Babin, B. J., Anderson, R. E., \& Tatham, "Multivariate data analysis," Prentice hall Up. Saddle River, NJ., vol. 5, no. Multivariate data analysis, 1998.

[87] C. M. Ringle, S. Wende, and A. Will, "SmartPLS 2.0 (Beta). Hamburg," Available in http://www. smartpls. de, 2005.

[88] K. K.-K. Wong, "Partial least squares structural equation modeling (PLS-SEM) techniques using SmartPLS," Mark. Bull., vol. 24, no. 1, pp. 1-32, 2013.

[89] W. W. Chin, "The partial least squares approach to structural equation modeling," Mod. methods Bus. Res., vol. 295, no. 2, pp. 295-336, 1998.

[90] B. AL KURDI, "Healthy-Food Choice and Purchasing Behaviour Analysis: An Exploratory Study of Families in the UK." Durham University, 2016.

[91] L. J. Cronbach and L. Furby, "How we should measure" change": Or should we?," Psychol. Bull., vol. 74, no. 1, p. 68, 1970. https://doi.org/10.1037/h0029382

[92] C. E. Werts, R. L. Linn, and K. G. Jöreskog, "Intraclass reliability estimates: Testing structural assumptions," Educ. Psychol. Meas., vol. 34, no. 1, pp. 25-33, 1974. https://doi. org $/ 10.1177 / 001316447403400104$

[93] D. Gefen, D. Straub, and M.-C. Boudreau, "Structural equation modeling and regression: Guidelines for research practice," Commun. Assoc. Inf. Syst., vol. 4, no. 1, p. 7, 2000. https://doi.org/10.17705/1 cais.00407

[94] J. C. Nunnally and I. H. Bernstein, "Psychometric theory," 1978. 
[95] G. A. Churchill Jr, “A paradigm for developing better measures of marketing constructs,” J. Mark. Res., pp. 64-73, 1979.

[96] J. C. Anderson and D. W. Gerbing, "Structural equation modeling in practice: A review and recommended two-step approach.," Psychol. Bull., vol. 103, no. 3, p. 411, 1988. https://doi.org/10.1037//0033-2909.103.3.411

[97] R. F. Falk and N. B. Miller, A primer for soft modeling. University of Akron Press, 1992.

[98] C. Fornell and D. F. Larcker, "Evaluating structural equation models with unobservable variables and measurement error," J. Mark. Res., pp. 39-50, 1981. https://doi.org/10.1177/ 002224378101800104

[99] D. Gefen and D. W. Straub, "The relative importance of perceived ease of use in IS adoption: A study of e-commerce adoption,” J. Assoc. Inf. Syst., vol. 1, no. 1, p. 8, 2000.

[100] Y.-C. Lin, Y.-C. Chen, and R. C. Yeh, "Understanding college students' continuing intentions to use multimedia e-learning systems," World Trans. Eng. Technol. Educ., vol. 8, no. 4, pp. 488-493, 2010.

[101] S.-C. Lin, S. F. Persada, and R. Nadlifatin, "A study of student behavior in accepting the Blackboard Learning System: A Technology Acceptance Model (TAM) approach," in Computer Supported Cooperative Work in Design (CSCWD), Proceedings of the 2014 IEEE 18th International Conference on, 2014, pp. 457-462. https://doi.org/10.1109/cscwd. $\underline{2014.6846888}$

[102] S.-H. Liu, H.-L. Liao, and C.-J. Peng, "Applying the technology acceptance model and flow theory to online e-learning users' acceptance behavior," E-learning, vol. 4, no. H6, p. H8, 2005.

[103] S. A. S. Salloum and K. Shaalan, "Investigating students' acceptance of E-learning system in Higher Educational Environments in the UAE: Applying the Extended Technology Acceptance Model (TAM)." The British University in Dubai, 2018.

[104] M. Al-Emran and S. A. Salloum, "Students' Attitudes Towards the Use of Mobile Technologies in e-Evaluation," Int. J. Interact. Mob. Technol., vol. 11, no. 5, pp. 195-202, 2017. https://doi.org/10.3991/ijim.v11i5.6879

[105] S. A. Salloum, M. Al-Emran, R. Khalaf, M. Habes, and K. Shaalan, "An Innovative Study of E-Payment Systems Adoption in Higher Education: Theoretical Constructs and Empirical Analysis.," Int. J. Interact. Mob. Technol., vol. 13, no. 6, 2019. https://doi.org/1 $\underline{0.3991 / \text { ijim.v13i06.9875 }}$

[106] M. Alshurideh, S. A. Salloum, B. Al Kurdi, and M. Al-Emran, "Factors affecting the Social Networks Acceptance: An Empirical Study using PLS-SEM Approach," in 8th International Conference on Software and Computer Applications, 2019. https://doi.org/10. $1145 / 3316615.3316720$

[107] S. A. Salloum and M. Al-Emran, "Factors affecting the adoption of e-payment systems by university students: extending the TAM with trust," Int. J. Electron. Bus., vol. 14, no. 4, pp. 371-390, 2018. https://doi.org/10.1504/ijeb.2018.10019536

[108] M. Habes, M. Alghizzawi, S. A. Salloum, and M. F. Ahmad, "The Use of Mobile Technology in the Marketing of Therapeutic Tourist Sites: A Critical Analysis," Int. J. Inf. Technol. Lang. Stud., vol. 2, no. 2, 2018.

[109] A. Tarhini, K. Hone, X. Liu, and T. Tarhini, "Examining the moderating effect of individual-level cultural values on users' acceptance of E-learning in developing countries: a structural equation modeling of an extended technology acceptance model," Interact. Learn. Environ., vol. 25, no. 3, pp. 306-328, 2017. https://doi.org/10.1080/10494820.2015. $\underline{1122635}$

[110] S. A. Salloum, M. Al-Emran, K. Shaalan, and A. Tarhini, "Factors affecting the E-learning acceptance: A case study from UAE," Educ. Inf. Technol., pp. 1-22, 2018. https://doi.org $\underline{10.1007 / \mathrm{s} 10639-018-9786-3}$ 
[111] W. Wongvilaisakul and S. Lekcharoen, "The acceptance of e-Learning using SEM approach: A case of IT Literacy development for PIM students," in Electrical Engineering/Electronics, Computer, Telecommunications and Information Technology (ECTICON), 2015 12th International Conference on, 2015, pp. 1-6. https://doi.org/10.110 9/ecticon.2015.7207117

[112] M. Mahmodi, "The Analysis of the Factors Affecting the Acceptance of E-learning in Higher Education,” Interdiscip. J. Virtual Learn. Med. Sci., vol. 8, no. 1, 2017. https://doi.o rg/10.5812/ijvlms. 11158

[113] G. U. D. Shah, M. N. Bhatti, M. Iftikhar, M. I. Qureshi, and K. Zaman, "Implementation of technology acceptance model in e-learning environment in rural and urban areas of Pakistan,” World Appl. Sci. J., vol. 27, no. 11, pp. 1495-1507, 2013.

[114] H. Al Dmour, M. Alshurideh, and F. Shishan, "The influence of mobile application quality and attributes on the continuance intention of mobile shopping," Life Sci. J., vol. 11, no. 10, pp. 172-181, 2014.

[115] Y.-C. Lee, "An empirical investigation into factors influencing the adoption of an elearning system," Online Inf. Rev., vol. 30, no. 5, pp. 517-541, 2006.

[116] E. T. Khor, "An analysis of ODL student perception and adoption behavior using the technology acceptance model," Int. Rev. Res. Open Distrib. Learn., vol. 15, no. 6, 2014.

[117] I. Govender and I. Rootman-le Grange, "Evaluating the Early Adoption of Moodle at a Higher Education Institution," in European Conference on e-Learning, 2015, p. 230.

[118] H. Motaghian, A. Hassanzadeh, and D. K. Moghadam, "Factors affecting university instructors' adoption of web-based learning systems: Case study of Iran," Comput. Educ., vol. 61, pp. 158-167, 2013. https://doi.org/10.1016/j.compedu.2012.09.016

[119] A. Tarhini, K. Hone, and X. Liu, "Extending the TAM model to empirically investigate the students' behavioural intention to use e-learning in developing countries," in Science and Information Conference (SAI), 2013, 2013, pp. 732-737.

[120] A. Tarhini, K. Hone, and X. Liu, "Factors affecting students' acceptance of e-learning environments in developing countries: a structural equation modeling approach," Int. J. Inf. Educ. Technol., vol. 3, no. 1, p. 54, 2013. https://doi.org/10.7763/ijiet.2013.v3.233

[121] R. M. Al-dweeri, Z. M. Obeidat, M. A. Al-dwiry, M. T. Alshurideh, and A. M. Alhorani, "The impact of e-service quality and e-loyalty on online shopping: moderating effect of esatisfaction and e-trust," Int. J. Mark. Stud., vol. 9, no. 2, p. 92, 2017. https://doi.org/10.55 39/ijms.v9n2p92

\section{Authors}

Muhammad AIShurideh is working for the College of Business Administration University of Sharjah in UAE as a full time faculty member and for the School of Business - University of Jordan in Jordan as well. Regarding the teaching, he has the responsibilities to teach a wide range of marketing and business topics for both undergraduate and postgraduate students. The D. has more than 40 published papers in different marketing and business topics mainly CRM and Customer Retention. D. Alshurideh is used to publish in good ranked journals such as Journal of Marketing Communications and International Journal of Electronic Customer Relationship Management. You can contact D. Alshurideh via email at: m.alshurideh@ju.edu.jo or malshurideh@sharjah.ac.ae. 
Said A. Salloum had graduated from The British University in Dubai with a distinction with MSc in Informatics (Knowledge and Data Management). He got his Bachelor's degree in Computer Science from Yarmouk University. Currently, He is working at the University of Sharjah "Research Institute of Sciences and Engineering (RISE)" as a researcher on different research areas in Computer Science such as data analysis, machine learning, knowledge management, and Arabic Language Processing. Salloum is an Oracle expert since 2013 along with various recognized international certificates that are issued by Oracle.

Barween Al Kurdi is an assistant Professor in Marketing and she is working for Amman Arab University - Faculty of Business - Marketing Department. She is a member of large number of committees and mainly the social committee. She used to publish in good ranked journals such as Journal of Marketing Communications and International Journal of Marketing Studies. You can contact D. Al Kurdi at balkurdi@aau.edu.jo

Azza Abdel Monem is an Assistant Professor at, Faculty of Computers \& Information, Ain Shams University, Cairo, Egypt. She received her B.S. in Electronics and Communication Engineering, Faculty of Engineering, Cairo University, July 1992. And Ph.D. in Computer Engineering Dept. of Computer and Engineering, Faculty of Engineering, Cairo University, July 2006. Her research interests include Web information integration, education technology, and knowledge discovery from databases, natural language processing, machine learning, data mining, and computer security.

Khaled Shaalan is a full professor of Computer and Information Sciences at the British University in Dubai (BUiD). He is also a tenure professor at Cairo University. Prof Khaled is an Honorary Fellow at the School of Informatics, University of Edinburgh (UoE). He is currently the Head of $\mathrm{PhD}$ in Computer Science, MSc in Informatics, and MSc in IT Management programs. His main area of interest includes computational linguistics. He is an authority in the field of Arabic Natural Language Processing, and commands a great respect among the research community in the Arab world. He is the Head of Natural Language Research Group at BUiD. Prof Khaled has several research publications in his name in highly reputed journals such as IEEE Transactions on Knowledge and Data Engineering, Computational Linguistics, Journal of Natural Language Engineering, Journal of the American Society for Information Science and Technology, Expert Systems with Applications, SoftwarePractice \& Experience, Journal of Information Science, and Computer Assisted Language Learning to name a few. He has guided several Doctoral and Master Students in the area of Arabic Natural Language Processing and Knowledge Management. He has done extensive research in the field of Arabic Named Entity Recognition and currently working on Arabic Question Answering.

Article submitted 2019-02-09. Resubmitted 2019-08-10. Final acceptance 2019-08-11. Final version published as submitted by the authors. 


\section{Appendix A. Constructs and items}

\section{System Quality}

- At the busiest time of the day, the response of the Mobile Learning Platform (MLP) is quick.

- I consider Mobile Learning Platform (MLP) interaction to be satisfactory.

- I consider the Mobile Learning Platform (MLP) functions to be satisfactory.

- I am satisfied with the Mobile Learning Platform (MLP) functions.

\section{Information Quality}

- Information, which is relevant to my necessities, is acquired through Mobile Learning Platform (MLP).

- Thorough information is given by Mobile Learning Platform (MLP).

- The Mobile Learning Platform (MLP) produced information is up-to-date enough for my needs.

- The Mobile Learning Platform (MLP) provides useful information for my study.

\section{Content Quality}

- The updated information is usually provided by the Mobile Learning Platform (MLP).

- Learning content which I require can be provided by the Mobile Learning Platform (MLP).

- I think there is great value of the information I will acquire from Mobile Learning Platform (MLP).

- The Mobile Learning Platform (MLP) often provides the updated information.

\section{Service Quality}

- The Mobile Learning Platform (MLP) provides the right solution to my request.

- The Mobile Learning Platform (MLP) has a good interface to communicate my needs.

- The Mobile Learning Platform (MLP) gives me prompt service

- Overall, support services of the Mobile Learning Platform (MLP) are satisfactory.

\section{Perceived Ease of Use}

- There is clarity and understanding in my interaction with Mobile Learning Platform (MLP).

- I think it is easy to make the Mobile Learning Platform (MLP) act how I want it to.

- The Mobile Learning Platform (MLP) is easy to use for me.

- I find the Mobile Learning Platform (MLP) easy to use. 


\section{Perceived Usefulness}

- The learning process will be made easier by using the Mobile Learning Platform (MLP) tool.

- I consider the Mobile Learning Platform (MLP) to assist my learning.

- My productivity is elevated through the utilization of Mobile Learning Platform (MLP) in my work.

- I find the Mobile Learning Platform (MLP) to be useful in my learning.

\section{Intention to Use the Mobile Learning Platforms}

- I will make use of the Mobile Learning Platform (MLP) regularly in the forthcoming time.

- I intend to make use of the content and functions of Mobile Learning Platform (MLP) for providing assistance to my academic activities. 